\title{
Determinants of Farmers' Access to Extension Services and Adoption of Technical Inputs: Evidence from India
}

\author{
Ankit Nagar ${ }^{*}$ Dinesh Kumar Nauriyal, Sukhpal Singh \\ Department of Humanities and Social Sciences, Indian Institute of Technology, Roorkee, Uttarakhand, India
}

Received May 8, 2021; Revised June 15, 2021; Accepted July 19, 2021

\section{Cite This Paper in the following Citation Styles}

(a): [1] Ankit Nagar, Dinesh Kumar Nauriyal, Sukhpal Singh, " Determinants of Farmers' Access to Extension Services and Adoption of Technical Inputs: Evidence from India," Universal Journal of Agricultural Research, Vol. 9, No. 4, pp. 127-137, 2021. DOI: 10.13189/ujar.2021.090404.

(b): Ankit Nagar, Dinesh Kumar Nauriyal, Sukhpal Singh (2021). Determinants of Farmers' Access to Extension Services and Adoption of Technical Inputs: Evidence from India. Universal Journal of Agricultural Research, 9(4), 127-137. DOI: 10.13189/ujar.2021.090404.

Copyright $\mathrm{O} 2021$ by authors, all rights reserved. Authors agree that this article remains permanently open access under the terms of the Creative Commons Attribution License 4.0 International License

\begin{abstract}
This paper examines the determinants of farmers' access to agricultural extension services and adoption of technical inputs. It also attempts to identify what works best for Indian agriculture. Based upon all-India unit-level data of 35,200 farming households surveyed by the National Sample Survey Organisation (NSSO) under the $70^{\text {th }}$ round in 2013, it applies the binary logistic regression model. The study underlines that the 'Access' to agricultural extension services does not guarantee 'Adoption' of the technologies or better farm practices, as all the variables emerging as significant in case of 'Access' do not emerge as significant for 'Adoption'. The study finds the strong influence of personal and household characteristics on both 'Access' and 'Adoption'. However, socioeconomic and technology variables such as caste, gender, religion, and usage of ICT are found to be important for 'Access' but not for the 'Adoption'. The paper underlines that physical forms of extension services are far more important than the modern ICT driven services in the developing countries like India. It, therefore, recommends significant strengthening of these services with more generous government support.
\end{abstract}

Keywords Agriculture, Access, Adoption, Extension Services, ICT, India, NSSO

\section{Introduction}

A considerable number of research studies across the globe have established beyond doubt that knowledge-intensive agricultural extension services are instrumental in substantially improving farm productivity, agro-management practices, diversifying farming systems and eventually farmers' incomes $[6,12,13]$. Extension services have evolved from traditional tasks such as dissemination and transfer of new technology and latest farm management information to a broader advisory service role that also addresses issues related to risk management, environmental sustainability, marketing, etc. [28] and positively impacts the choices and practices of the farming community resulting in better and risk-hedging diversified output $[4,12]$. These services have also moved exclusively from public sector centric domain to a basket of many diversified resources, involving private sector and NGOs, enabling access to more extensive choices of farm-related advice. The structural vicissitudes exacerbated this transformation brought about by a fast rise in economic development, changes in the composition of consumption basket, the emergence of new agricultural technologies and practices, unprecedented rise in the use of ICT, and diminishing government support [28, 5, 39].

Even in the case of India, the green revolution that transformed the Indian agriculture and made India from a net importer to a net exporter of agro-products would not have fructified in the absence of effective and efficient agricultural extension services $[19,10]$. It may be mentioned here that extension services in India are highly skewed towards crop husbandry. Still, around 70 percent 
of agricultural research and education budget and 92 percent of the agricultural extension budget caters to the crop-husbandry alone [27], which gives rise to the impression that India has yet not adequately reoriented its public extension services to address the serious issues of rain-fed agriculture, oilseeds, pulses, and other crops that are important for food security and nutrition. Moreover, the consumption demand is swiftly shifting from cereals to high-value vegetables, fruits, meat, and dairy products [29]. The growth in the high-value agriculture products has been twice or sometimes even thrice that of crop production. For instance, between 2001-02 and 2013-14, livestock contributed 26.3 percent, food-grains 15.4 percent, and fruits and vegetables 14 percent to the gross value of output from agriculture and allied activities [18]. Despite these advancements, the persistent overemphasis on cereals over the entire food and agricultural value chain appears to have cast doubt on the relevance and use of state extension services, particularly in light of evolving consumer preferences and, consequently, demand dynamics.

While 'Access' remains the core issue, 'Adoption' is particularly important as it helps farmers to reduce the gap between latent and actual farm yields. It may be noted that existing literature on the subject has found evidence of a serious gap between 'access' and 'adoption' on account of imperfect information, weak credit markets, and market inefficiencies [40, 41].

The paper identified the determinants of farmers' access to the extension services and adoption of the technical advice available from the various extension sources.

Existing research on the subject sheds light on the various determinants of 'Access' and 'Adoption'. Some of them are the age of the head of the household $(\mathrm{HOH})$, farm size, distance from the market, distance from the nearest technology adopter, farming experience, farmers' education, the market orientation of farming, ownership of the farm and a few other factors. However, there might be some other contextual factors that may influence the choice of the farmers and efficiency of content and delivery mechanism of the extension services, as farmers are heterogeneous groups. This heterogeneity comes from divergent socioeconomic circumstances, farm size, exposure to the new knowledge and technology and their receptiveness and adaptation levels. A fairly good number of studies have explored the information-seeking behaviour of the farmers and the types of information that they generally seek from extension workers and others, and also the likelihood of adoption of technology [20, 4, 13]. As per the National Sample Survey Organisation (NSSO) data, only 13,344 households, out of a total sample of 35,200 , have had access to the agricultural extension services which comes to 37.91 percent of the total sample. Out of these, over 90 percent of the lower marginal farmers focus on one to two sources of information. In comparison, this proportion comes to 84 percent, 83 percent, 79 percent, 75 percent, and 67 percent for marginal, small, semi-medium, medium, and large farming households respectively. It suggests that with a rise in the size of the landholding, farmers tend to diversify their sources of information. Similarly, with a rise in the education of the head of the household $(\mathrm{HOH})$, the diversification in sources of information increased. Region-wise, the Southern region leads in terms of access to agricultural extension services, with 48.42 percent of sample households having access, compared to 41 percent, 38.28 percent, 36.98 percent, 32.96 percent, and 32.82 percent of sample households in the Central, Western, Eastern, North, and North-East regions, respectively. Table 1 highlights the summary of source-wise and region-wise access to agricultural extension services.

Table 1. Source-wise and region-wise access to agricultural extension services in India in 2013

\begin{tabular}{|c|c|c|c|c|c|c|c|c|}
\hline $\begin{array}{l}\text { Region-wise number of farmers who actually } \\
\text { accessed either one or more of the sources }\end{array}$ & $\begin{array}{l}\text { Source of Agri. Extn. Services } \\
\text { /Regions } \\
\text { e number of farmers who actually } \\
\text { either one or more of the sources }\end{array}$ & North & $\begin{array}{c}\text { North- } \\
\text { East } \\
1676\end{array}$ & Central & $\begin{array}{c}\text { East- } \\
\text { ern } \\
2627\end{array}$ & $\begin{array}{l}\text { West- } \\
\text { ern } \\
1576\end{array}$ & $\begin{array}{l}\text { South- } \\
\text { Ern } \\
3249\end{array}$ & India \\
\hline $\mathrm{SN}$ & Source & \multicolumn{7}{|c|}{ Source-wise access in percentage (out of total accessed 13344) } \\
\hline 1. & Extension agent & 7.47 & 30.42 & 22.27 & 15.80 & 19.04 & 22.04 & 18.07 \\
\hline 2. & Krishi Vigyan Kendra & 9.71 & 3.82 & 7.01 & 6.74 & 12.44 & 15.17 & 9.79 \\
\hline 3. & Agricultural University /College & 7.85 & 1.97 & 1.52 & 0.99 & 4.06 & 3.60 & 4.21 \\
\hline 4. & Private commercial agent & 14.84 & 3.70 & 8.72 & 17.78 & 16.05 & 16.13 & 13.95 \\
\hline 5. & Progressive Farmer & 35.87 & 28.58 & 62.09 & 53.83 & 59.01 & 41.58 & 44.58 \\
\hline 6. & Radio/TV/ newspaper /internet & 57.13 & 56.62 & 37.16 & 48.29 & 51.02 & 63.93 & 54.16 \\
\hline 7. & Veterinary department & 28.03 & 26.55 & 12.23 & 14.85 & 19.54 & 32.81 & 24.11 \\
\hline 8. & NGO & 2.37 & 5.43 & 3.22 & 2.51 & 1.65 & 1.94 & 2.63 \\
\hline
\end{tabular}

Notes: The percentage figures from column three to nine may not add to 100 as the sample households have had access to multiple sources. Source: Authors' calculation from NSSO $70^{\text {th }}$ round data. 
Table 2. Number of sources of information accessed by the farmers in India, 2013 (region wise)

\begin{tabular}{|c|c|c|c|c|c|c|c|}
\hline \multirow[b]{2}{*}{ No. of sources of advice } & \multicolumn{7}{|c|}{ Percentage of farmers who have accessed the extension services } \\
\hline & North & $\begin{array}{c}\text { North- } \\
\text { East }\end{array}$ & Central & Eastern & Western & Southern & India \\
\hline $\begin{array}{l}\text { Total (in no) } \\
\text { (in percent) }\end{array}$ & $\begin{array}{c}3161 \\
(32.96)\end{array}$ & $\begin{array}{c}1676 \\
(32.82)\end{array}$ & $\begin{array}{c}1055 \\
(41.00)\end{array}$ & $\begin{array}{c}2627 \\
(36.98)\end{array}$ & $\begin{array}{c}1576 \\
(38.28)\end{array}$ & $\begin{array}{c}3249 \\
(48.42)\end{array}$ & $\begin{array}{c}13344 \\
(37.91)\end{array}$ \\
\hline 1 & 61.02 & 58.11 & 64.83 & 58.62 & 46.26 & 44.2 & 54.65 \\
\hline 2 & 23.7 & 30.37 & 24.27 & 28.25 & 31.79 & 28.25 & 27.54 \\
\hline 3 & 9.4 & 8.83 & 5.78 & 9.59 & 17.2 & 16.31 & 11.68 \\
\hline 4 & 3.39 & 1.73 & 2.94 & 2.93 & 3.05 & 7.66 & 4.05 \\
\hline 5 & 2.06 & 0.89 & 1.42 & 0.53 & 1.14 & 2.89 & 1.66 \\
\hline 6 & 0.32 & 0.06 & 0.66 & 0.04 & 0.51 & 0.52 & 0.33 \\
\hline 7 & 0.06 & 0.00 & 0.09 & 0.04 & 0.06 & 0.09 & 0.06 \\
\hline 8 & 0.06 & 0.00 & 0.00 & 0.00 & 0.00 & 0.06 & 0.03 \\
\hline Total & 100 & 100 & 100 & 100 & 100 & 100 & 100 \\
\hline
\end{tabular}

Source: Authors' calculation from NSSO $70^{\text {th }}$ Round.

As is evident from Table 1, Radio/TV/ Newspaper /Internet, followed by progressive farmers (54.16 percent and 44.58 respectively) are the most utilised sources of information with variations across the regions. For instance, while in Central, Eastern, and Western regions, mostly progressive farmers were consulted for technical inputs, Radio/TV/Newspaper/Internet sources dominated in North, North-East, and Southern regions. The emergence of these alternatives has severely limited the role of public extension services which are marked by low dependability attributable to poor quality and reliability of the professional advice rendered [38, 34]. Studies have also revealed that public sector extension services benefit large farmers rather than small ones [13]. A study, based on NSSO 2005 data, also reported that the extension services needs of the farmers were primarily met by progressive farmers (16.7 percent), closely followed by input dealers (13.1 percent), radio broadcasts (13 percent), and finally by the public service extension agents (5.75 percent) [30]. Another study, conducted by Reardon et al. in 2011 in Uttar Pradesh state, reported that only 7 percent of the sample farmers took advantage of specific government extension services. An additional 18 percent of the sample farmers were served by other public sector extension sources such as Radio, university extension centres, plant protection units, and Krishi Vigyan Kendras (KVKs). KVKs are part of National Aricultural Research System (NARS) for assessing location specific technology modules in agriculture and allied enterprises, through technology assessment, refinement and demonstrations. Another survey of farmers in Tamil Nadu in 2010 also reported almost the same results [10]. It is further reported that the choice of information source was primarily determined by proximity (33.7 percent), assured quality (21.1 percent), sole option (20.6 percent), and timely availability (13.7 percent) [10]. Table 2 provides information about the number of sources accessed by farmers.
As is indicated in Table 2, around 55 percent of the farmers access only one out of eight sources of agriculture extension services. In comparison, 28 percent of the farmers access two sources of agriculture extension. On all India basis, over 82 percent of the farmers were found to be using not more than two sources. The data in Table 2 also reveal that the Southern and Western regions are far more agile in utilising various sources of information. It suggests that not all the extension services are found to be accessible/relied upon by the farmers.

When it comes to the conversion of access to adoption, the prior literature has well documented the positive and significant impact of 'Access' on 'Adoption' of the latest farm technologies and practices. It has, however, also been reported that adoption is only a fraction of access as access every time does not transform into adoption $[6,17$, 40]. As per NSSO 70th round also, 84.39 percent of 13,344 farming households who accessed the extension services, have adopted their technical advice. It suggests that access to extension services meaningfully promotes the 'Adoption' of technical advice.

\section{Methodology}

This study is based on secondary data from the NSSO 70th round, conducted in the calendar year of 2013, comprising 35,200 households. Out of these, only 13,334 (37.9 percent) households have reported having accessed agricultural extension services. This study used the binary logistic regression model, and the research hypotheses regarding the relationship between the dependent and independent variables for both 'access' and 'adoption' are based on the 'prior art' and additional factors. The functional form of the logistic regression model for 'access to agricultural extension services' is given below.

Logit (Access) $=\boldsymbol{\beta} \mathbf{0}+\boldsymbol{\beta} \mathbf{1}$ education $+\boldsymbol{\beta} 2$ age + $\boldsymbol{\beta} 3$ household size $+\boldsymbol{\beta} 4$ training $+\boldsymbol{\beta}$ 5Principal source of 
income $+\boldsymbol{\beta} 6$ awareness about MSP $+\boldsymbol{\beta} 7$ social group + $\boldsymbol{\beta} 8$ gender $+\boldsymbol{\beta}$ 9religion $+\boldsymbol{\beta} 10$ availability of credit $+\boldsymbol{\beta} 11$ farm size $+\boldsymbol{\beta} 12$ assured means of irrigation $+\boldsymbol{\beta} 13$ Region $+\mathcal{E}$

Except for two additional variables i.e., Use of ICT and Frequency of Extension Contacts, the functional form of 'adoption of technical inputs from agricultural extension services' (henceforth referred to as 'Adoption') is nearly identical to that of 'access to agricultural extension services' (henceforth referred to as 'Access'):

\section{The Variables}

Since this study focuses on the identification of the determinants of the 'Access', a model has been developed wherein 'Access' is a dependent binary variable implying that the household either has or does not have access to the extension services. The explanatory variables comprise personal and household attributes, socioeconomic factors, wealth indicators, regional characteristics, and others. The choice of these variables is guided by existing theoretical and empirical literature and the ground realities. Another critical issue that has been discussed is that of the determinants of the 'Adoption'. In all likelihood, adoption is a by-product of the access to the extension services. Since most of the variables are likely to be universal, they are presented in Table 3 .

The summary statistics of the variables selected for the study are given in Table 4. It suggests that the educational attainment of the farmers in India is relatively low. Out of a total 35200 sample of farmers, only 5.29 percent were graduate and above, and less than one percent held the diploma/certificate. This indicates severe knowledge-deficit in Indian agriculture. Table 4 demonstrates that a majority of farm households (65 percent) have cultivation as the principal source of income, followed by wages and salaries (19.78 percent). Livestock and non-farm activities are the principal sources of income for 4.34 percent and 4.32 percent of farm households, respectively. Surprisingly, only 20 percent of the farmers are aware of the minimum support price (MSP). It indicates the inadequate awareness of the farmers of the critical underlying issues in agriculture. The distribution of sample households by social group shows that other backward class (OBC) constitutes the highest share (40.32 percent), followed by Others (27.48 percent). The gender-wise distribution indicates that males head more than 91 percent of households. Table 4 further reveals that institutional credit is accessible to only 51.64 percent of farmers, and the rest of the farmers depend on informal sources, which charge a high rate of interest. It may be noted that only 3.56 percent of farmers have attended training in agriculture-related issues. In terms of farm household distribution by operational holding size, the majority of farmers ( 54.50 percent) have land that is less than one hectare in size. Another 28.17 percent of farmers operate farms with an area of one to two hectares. Thus, about 83 percent of farmers in India are small and marginal landholders. Large farmers constitute only 0.73 percent of the total farmers. Almost 52 percent of the households have unirrigated cultivable land. About 54 percent of farmers use the ICT tools for accessing the agriculture-related information. Distribution of sample households by the frequency of extension contract indicates that need-based contact has the highest percentage (45.72 percent) followed by seasonal (20.44percent) and casual contacts (13.73 percent). Table 4 also highlights that the most populous regions of India, i.e., Northern, Eastern and Southern regions constitute 67 percent of the sample. 
Table 3. Definition of variables and hypotheses

\begin{tabular}{l} 
Variable \\
\hline Dependent Variable \\
Access to Extension Services \\
Adoption of technical input \\
Independent Variables \\
Personal and Household \\
Attributes
\end{tabular}

Education

Age

Household Size

Training in agriculture

Principal source of income

Awareness about MSP

$($ Yes $=1$, no $=0)$

Socioeconomic Variables

Social Group

Gender of $\mathrm{HOH}$

Religion

Availability of credit

Wealth Indicator/Farm

Characteristics

Farm size

Assured means of irrigation (Irrigated $=1$, Otherwise $=0$ )

Regional Characteristics

Region

Other Variables (applicable only to the Adoption of Technical Inputs of Extension Services)

Use of ICT

Frequency of extension contact
Description/Definition/measurement

What prior art says about the impact of independent variable on the dependent variable.

If access of any of the given extension service $=1$, otherwise $=0$

If adopted technical advice from any of the extension service $=1$, otherwise $=0$

Farmers Education, divided into six categories: illiterate, below primary, secondary to higher secondary, Diploma/Certificate, graduation and above.

Age of the farmer (in Years)

No. of members in the household

If got training in agriculture $=1$, otherwise 0

The source generating maximum income considered as Principal source and divided into six categories, cultivation, livestock, other agricultural activity, non-agricultural enterprise, wage \& salaried and other (Pension, remittances etc)

If aware about the Minimum Support Price=1, otherwise $=0$

Social Group category of the household divided into Scheduled tribe (ST), Scheduled cast (SC), Other backward class $(\mathrm{OBC})$ and others.

If male $=1$, otherwise 0

Religion of the household

if accessed $=1$, otherwise $=0$ categories, lower marginal, marginal, small, semi-medium, medium and large.

If a farmer has an assured source of irrigation=1, otherwise $=0$

All India is divided in six regions, northern, north-east, central, eastern, western and southern

Positive impact is reported by Wossen et al. 2017; Olumba and Rahji, 2014; Arias et al. 2013; Elias et al. 2013).

Negative impact reported by Abdallah and Rahaman 2016.

Positive impact is reported by Abdallah and Rahaman, 2016; Wossen 2017; Mignouma et al. 2011),

Negative relationship reported by Elias et al. 2013; Nlerum, 2013; Akudugu 2012)

Positive impact is reported by Yimer et al.

2019; Abdallah and Rahaman 2016.

Negative Impact is reported by Anang et al. 2019.

Positive impact is reported by Arias et al.

2013.

To be explored

To be explored

Marginalised social groups have poor 'Access' and 'Adoption'. (Krishna et al. 2019, Rao, 2017; Balasubramaniam et al. 2014; Singh et al. 2013; Anderson 2011; Iversen et al. 2010)

Female headed households have poor 'Access' and 'Adoption' (Elias et al. 2013; Quisumbing et al. 2014; Jafry and Sulaiman 2013; Lavision, 2013)

To be explored

Positive impact is reported by Lavison, 2013; Mariano et al. 2012.

Positive impact of farm size (Oluwasusi 2014; Lavison, 2013; Admassie and Ayele, 2010; Franklin et al., 2011; Abdulai et al. 2005; Bonabana-Wabbi, 2002).

No impact (Bonabana-Wabbi, 2002; Franklin Simtowe et al., 2006 and Samiee et al., 2009).

Positive impact (David and Otsuka 1994; Estudillo and Otsuka 2006).

To be explored

Positive impact (Parmar et al. 2019)

if access television (TV), radio, internet and No significant impact (Franklin et al., newspaper $=1$, otherwise $=0$ 2011)

Divided into six categories, daily, weekly, monthly, Positive impact (Franklin et al., 2011; seasonally, need-based and casual contact.
Nlerum (2013)

Source: Authors' calculation (NSSO $70^{\text {th }}$ round) 
Table 4. Summary Statistics of Variables

\begin{tabular}{|c|c|c|}
\hline Variable (Definition / Measurement) & Percentages & Mean \\
\hline \multicolumn{3}{|l|}{ Education (Years spent in formal schooling) } \\
\hline Illiterate & $34.41(12113)$ & \\
\hline Below primary & $13.75(4838)$ & \\
\hline Primary to middle & $28.95(10190)$ & $5.09(3.42)$ \\
\hline Secondary to Higher secondary & $17.08(6011)$ & \\
\hline Diploma/certificate & $0.53(185)$ & \\
\hline Graduation and above & $5.29(1861)$ & \\
\hline Age ( Number of Years) & & $50.67(13.48)$ \\
\hline Household Size (No. of members in the household) & & $5.36(2.69)$ \\
\hline \multicolumn{3}{|l|}{ Training in agriculture $(\mathrm{Yes}=1$, otherwise 0$)$} \\
\hline Yes & $3.56(1253)$ & \\
\hline No & $96.44(33947)$ & \\
\hline \multicolumn{3}{|l|}{ Principal source of income } \\
\hline Cultivation & $64.90(22845)$ & \\
\hline Livestock & $4.34(1529)$ & \\
\hline Other agricultural activity & $2.13(750)$ & \\
\hline Non-agricultural enterprise & $4.32(1521)$ & \\
\hline Wage \& salaried & $19.78(6961)$ & \\
\hline Other (Pension, remittance etc.) & $4.53(1594)$ & \\
\hline \multicolumn{3}{|l|}{ Awareness about MSP $($ Yes $=1$, no $=0)$} \\
\hline Yes & $20.05(7057)$ & \\
\hline No & 79.95 (28143) & \\
\hline \multicolumn{3}{|l|}{ Social Group } \\
\hline$S T$ & $18.96(6675)$ & \\
\hline$S C$ & $13.24(4659)$ & \\
\hline$O B C$ & $40.32(14193)$ & \\
\hline Other & $27.48(9673)$ & \\
\hline \multicolumn{3}{|l|}{ Gender of $\mathrm{HOH} \quad($ Male $=1$, otherwise 0$)$} \\
\hline Male & $91.58(32227)$ & \\
\hline Female & $8.42(2963)$ & \\
\hline \multicolumn{3}{|l|}{ Religion } \\
\hline Hindus & $79.64(28034)$ & \\
\hline Muslims & $9.40(3310)$ & \\
\hline Other & $10.95(3856)$ & \\
\hline \multicolumn{3}{|l|}{ Availability of credit $(\mathrm{Yes}=1, \mathrm{no}=0)$} \\
\hline Yes & $51.64(18176)$ & \\
\hline No & $\begin{array}{c}48.36 \\
(17024)\end{array}$ & \\
\hline Farm size ( In hectare) & & $1.50(1.86)$ \\
\hline Lower marginal (Up to 0.40) & $23.88(8407)$ & \\
\hline Marginal (0.41-1.00) & $20.61(7253)$ & \\
\hline Small (1.01-2.00) & $28.17(9916)$ & \\
\hline Semi-medium (2.01-4.00) & $20.97(7382)$ & \\
\hline Medium (4.01-10.00) & $5.65(1989)$ & \\
\hline Large $(10+)$ & $0.72(253)$ & \\
\hline \multicolumn{3}{|l|}{ Assured means of irrigation (Irrigated $=1$, Otherwise $=0$ ) } \\
\hline Irrigated Land & $48.41(17040)$ & \\
\hline Other Land & $51.51(18160)$ & \\
\hline \multicolumn{3}{|l|}{ Region } \\
\hline Northern & $27.24(9590)$ & \\
\hline North-east & $14.51(5107)$ & \\
\hline Central & $7.31(2573)$ & \\
\hline Eastern & $20.18(7103)$ & \\
\hline Western & $11.70(4117)$ & \\
\hline \multirow{2}{*}{\multicolumn{3}{|c|}{ Use of ICT tools $(\mathrm{Yes}=1, \mathrm{no}=0)$}} \\
\hline & & \\
\hline $\begin{array}{c}\text { Yes } \\
\text { Yos }\end{array}$ & $54.32(7244)$ & \\
\hline No & $45.68(6091)$ & \\
\hline \multicolumn{3}{|l|}{ Frequency of extension contact } \\
\hline Daily & $8.13(1084)$ & \\
\hline Weekly & $6.26(835)$ & \\
\hline Monthly & $5.71(762)$ & \\
\hline Seasonally & $20.44(2726)$ & \\
\hline Need-based & $45.72(6096)$ & \\
\hline Casual contact & $13.73(1831)$ & \\
\hline
\end{tabular}

Note: In column two, figures in parentheses are the frequency of the respective variables. In column three, figures in parentheses are standard deviation values of the respective mean.

Source: Authors' calculation (NSSO $70^{\text {th }}$ round) 
Table 5 provides more specific summary statistics which highlight that the farmers who have 'Access' and 'Adoption' have higher average education, larger farm size, better availability of the credit and awareness about the economic environment, as compared to those who have no 'Access'.

\section{Results and Discussion}

The results of our models, both for 'Access' and 'Adoption' are summed up in Table 6. Both the models are checked for multicollinearity among the independent variables, and no such problem is detected as the variance inflation factors (VIF) for all the variables was found to be less than 10 .

The results shown in Table 6 highlight the impact of the variables that demonstrate personal and household attributes. Almost all the variables, except for household size and age, were found to exercise a positive impact on 'Access', and some of them are equally critical for the 'Adoption'. Education, above the primary to the middle level, appears to be a threshold for positivity for 'Access' and 'Adoption', with the strongest impact at the secondary to higher secondary level. This level of education probably enhances the capacity of the farmer to appreciate the extension services, utilise new technology and use modern farm management practices, and also select and allocate the optimal quantity of various inputs that yield optimal returns. This result is consistent with the findings of earlier studies [36]. While the variable 'Age' appears to be significant for 'Access', it does not make great contributions to the 'Adoption', as has also been reported in an earlier study [36]. Household size appears to be insignificant for both, as was also reported by past research. Concerning the likelihood of 'Access' by the farmers who did any training in agriculture, the probabilities appear to be 121 percent higher than those who did not undergo any such training. This variable also turns out to be significant and exercises a positive influence on the 'Adoption'. This result is also supported by earlier studies $[25,26]$. In regard of the impact of the principal source of income of the farmers on 'Access', the results indicate that as compared to the reference category of 'Cultivation', the likelihood of farmer's 'Access' goes down by 61 percent in case of livestock and goes up 61 percent in case of 'other agricultural activities' such as plantation, orchard, forestry, logging, fishery etc. It could probably be so for the reason that 'other agricultural activities' are mostly knowledge and skill intensive and the use of the services of extension workers appears to be indispensable [20]. Except for farmers who earn the majority of their income from livestock, the rest of the farmers are found to be on the lower end of the 'Adoption' scale. Both the results appear to be logical, and along the expected lines, for the reason that households who get most of their incomes from off-farm activities would probably be marginal farmers with tiny pieces of land to work with. They may, therefore, focus more on their primary source of income rather than investing their time, money and energy in agriculture, where the returns may not meet most of their economic needs. The variable MSP has a significant impact on 'Access' but an insignificant impact on 'Adoption,' implying that other variables play a far more influential role.

Table 5. Farmers' 'Access' and 'Adoption'

\begin{tabular}{lccccccccc}
\hline & & \multicolumn{3}{c}{ Access of extension services } & \multicolumn{4}{c}{ Adoption of technical advice } \\
\cline { 3 - 9 } S.No. & Variable & & \multicolumn{2}{c}{ Access (13344) } & No Access (21856) & \multicolumn{2}{c}{ Adopter(11261) } & Non-adopter(2083) \\
\cline { 3 - 10 } & & Mean & S.D. & Mean & S.D & Mean & S.D. & Mean & S.D \\
1 & Education & 5.62 & 3.43 & 4.77 & 3.38 & 5.56 & 3.44 & 5.45 & 3.36 \\
2 & Age & 51.85 & 13.22 & 49.94 & 13.59 & 51.88 & 13.14 & 51.7 & 13.58 \\
3 & Household size & 5.47 & 2.77 & 5.29 & 2.64 & 5.46 & 2.76 & 5.48 & 2.84 \\
4 & Training & 0.059 & 0.24 & 0.020 & 0.14 & 0.06 & 0.24 & 0.04 & 0.20 \\
5 & Gender & 0.93 & 0.25 & 0.91 & 0.29 & 0.93 & 0.25 & 0.92 & 0.28 \\
6 & Farm size & 1.89 & 2.26 & 1.26 & 1.51 & 1.92 & 2.23 & 1.73 & 1.90 \\
7 & Availability of credit & 0.58 & 0.49 & 0.48 & 0.49 & 0.58 & 0.49 & 0.58 & 0.49 \\
8 & Awareness about MSP & 0.31 & 0.46 & 0.13 & 0.33 & 0.32 & 0.46 & 0.30 & 0.46 \\
9 & Use of ICT & - & - & - & - & 0.51 & 0.49 & 0.71 & 0.45 \\
\hline
\end{tabular}

Source: Authors' calculation (NSS $70^{\text {th }}$ round) 
Table 6. 'Access' and 'Adoption'

\begin{tabular}{|c|c|c|c|c|}
\hline \multirow[b]{2}{*}{ 'Access'/ 'Adoption' (Dependent Variable) } & \multicolumn{2}{|c|}{ Access } & \multicolumn{2}{|c|}{ Adoption } \\
\hline & Odds ratio & $\begin{array}{l}\text { Robust } \\
\text { Standard } \\
\text { error }\end{array}$ & Odds ratio & $\begin{array}{c}\text { Robust } \\
\text { Standard } \\
\text { error }\end{array}$ \\
\hline Constant & $0.053 * * *$ & 0.008 & 1.178 & 0.397 \\
\hline \multicolumn{5}{|l|}{ Independent Variables } \\
\hline \multicolumn{5}{|l|}{ Personal and household attributes } \\
\hline \multicolumn{5}{|l|}{ Education $\quad$ (Ref. Group= Illiterate) } \\
\hline Below primary & $1.178 * * *$ & 0.045 & 0.919 & 0.074 \\
\hline Primary to middle & $1.259 * * *$ & 0.040 & $1.151 * *$ & 0.080 \\
\hline Secondary to higher secondary & $1.384 * * *$ & 0.052 & $1.275^{* * *}$ & 0.101 \\
\hline Diploma/Certificate & $1.375 * *$ & 0.223 & $2.272 * * *$ & 0.799 \\
\hline Graduate and above & $1.359 * * *$ & 0.078 & $1.624 * * *$ & 0.193 \\
\hline Age & $1.022 * * *$ & 0.006 & 1.016 & 0.012 \\
\hline $\mathrm{Age}^{2}$ & $1.000 * * *$ & 0.000 & 1.000 & 0.000 \\
\hline Household size & 0.999 & 0.005 & 0.987 & 0.009 \\
\hline Training in agriculture (yes $=1$, otherwise $=0$ ) & $2.218 * * *$ & 0.143 & $1.174 *$ & 0.141 \\
\hline \multicolumn{5}{|l|}{ Principal source of income (Ref. $=$ Cultivation $)$} \\
\hline Livestock & $0.391 * * *$ & 0.030 & $1.790^{* *}$ & 0.432 \\
\hline Other agricultural activity & $1.615 * * *$ & 0.125 & 0.960 & 0.144 \\
\hline Non-agricultural enterprises & $0.858 * *$ & 0.052 & 0.993 & 0.131 \\
\hline Wage/salaried employment & $0.849 * * *$ & 0.030 & 0.896 & 0.068 \\
\hline Other & 0.940 & 0.060 & $0.718 * * *$ & 0.093 \\
\hline Awareness about MSP $\quad($ yes $=1$, otherwise $=0)$ & $2.231 * * *$ & 0.070 & 1.099 & 0.065 \\
\hline \multicolumn{5}{|l|}{ Socioeconomic Variables } \\
\hline \multicolumn{5}{|l|}{ Social Group $($ Ref.= ST) } \\
\hline $\mathrm{SC}$ & 1.063 & 0.052 & 1.035 & 0.110 \\
\hline $\mathrm{OBC}$ & $1.160 * * *$ & 0.046 & 1.141 & 0.095 \\
\hline Others & $1.293 * * *$ & 0.054 & 1.047 & 0.091 \\
\hline Gender $($ Male $=1$, otherwise $=0)$ & $1.092 *$ & 0.050 & 1.082 & 0.107 \\
\hline \multicolumn{5}{|l|}{ Religion $($ Ref. $=$ Hindus $)$} \\
\hline Muslims & $1.511 * * *$ & 0.066 & 1.110 & 0.095 \\
\hline Others & $0.787 * * *$ & 0.036 & 1.124 & 0.114 \\
\hline Availability of Credit (Yes $=1$, otherwise $=0$ ) & $1.193 * * *$ & 0.031 & 1.053 & 0.058 \\
\hline \multicolumn{5}{|l|}{ Wealth Indicators/Farm Characteristics } \\
\hline \multicolumn{5}{|l|}{ Farm size (in Hectare), $($ Ref.= Lower-marginal $(0.01-0.40)$} \\
\hline Marginal $(0.41-1.00)$ & $1.709 * * *$ & 0.068 & 1.037 & 0.094 \\
\hline Small $(1.01-2.00)$ & $1.892 * * *$ & 0.074 & 1.021 & 0.089 \\
\hline Semi-medium (2.01-4.00) & $2.119 * * *$ & 0.090 & $1.205^{* *}$ & 0.114 \\
\hline Medium (4.01-10.00) & $2.480 * * *$ & 0.149 & 1.148 & 0.142 \\
\hline Large $(10+)$ & $2.277 * * *$ & 0.312 & 1.531 & 0.473 \\
\hline Assured means of irrigation (irrigated $=1$, otherwise $=0$ ) & $1.737 * * *$ & 0.045 & $1.351 * * *$ & 0.076 \\
\hline \multicolumn{5}{|l|}{ Regional Characteristics } \\
\hline \multicolumn{5}{|l|}{ Region (Ref.=Northern) } \\
\hline North-east & $1.552 * * *$ & 0.073 & $1.969 * * *$ & 0.223 \\
\hline Central & $1.744 * * *$ & 0.089 & 1.095 & 0.124 \\
\hline Eastern & $1.211 * * *$ & 0.045 & 0.943 & 0.074 \\
\hline Western & $1.702 * * *$ & 0.074 & $0.876^{*}$ & 0.078 \\
\hline Southern & $2.111 * * *$ & 0.080 & $0.825^{* *}$ & 0.065 \\
\hline \multicolumn{5}{|l|}{ Other Variables } \\
\hline Use of ICT (yes=1, otherwise $=0$ ) & - & - & $0.559 * * *$ & 0.032 \\
\hline Contact with extension sources (Ref.= Daily) & - & - & & \\
\hline Weekly & - & - & 1.133 & 0.114 \\
\hline Monthly & - & - & $1.709^{* * *}$ & 0.191 \\
\hline Seasonally & - & - & $2.327 * * *$ & 0.204 \\
\hline Need-based & - & - & $5.103 * * *$ & 0.431 \\
\hline Casual contact & - & - & $1.315^{* * *}$ & 0.115 \\
\hline \multicolumn{5}{|l|}{ Other Statistics } \\
\hline Number of observations & & & & \\
\hline Wald $\operatorname{chi}^{2}(33)$ & & & & \\
\hline Prob $>\operatorname{chi}^{2}$ & & & & \\
\hline Pseudo $\mathrm{R}^{2}$ & & & & \\
\hline Correctly classified & 67.68 & rcent & 84.42 & rcent \\
\hline Area under ROC curve & & & & \\
\hline
\end{tabular}

Source: Authors' calculation

$* * * \mathrm{p}<0.01, * * \mathrm{p}<0.05, * \mathrm{p}<0.10$ 
Almost all the socio-economic variables significantly impact the 'Access' but appear to have not much relevance with the 'Adoption'. Caste, of course, appears to be important. For instance, while the ST and SC castes seem to be on the same plane, OBCs and 'Others' have an advantage of 'Access' on account of favourable socio-cultural-economic milieu and existence of strong social networks [7]. Ownership of the relatively larger size of cultivable land, as compared to the SCs and STs, also gives them the advantage of economies of scale. No significant difference is observed among the various social groups when it comes to the 'Adoption'. Although a study in Central Nepal region finds that the rate of adoption of soil conservation technology by lower and middle castes was higher than the upper caste farmers [37], we did not find any evidence to this effect in this study. The value and direction of the coefficient of the variable 'Gender' suggest that a male-headed household has 9 percent higher chances of having 'Access' than that of a female-headed household. It is probably due to socio-cultural norms since in the study region, males are particularly responsible for managing the livelihood sources. In support of this statement, a primary study based in Kenya [8] finds that more females attend the farmers field school (FFS) since socio-culturally women are supposed to manage the agricultural activities there and men fulfill the immediate monetary needs. Religion has also been found to have its role in 'Access'. For instance, the likelihood of access to extension services is 51 percent higher for Muslims, but 21 percent less for other religions, as compared to the reference category of Hindus. According to NSSO $70^{\text {th }}$ round data, there is only 37.95 percent of Hindu farmers accessing the extension services, as compared to 43.35 percent and 32.96 percent of Muslim and other religious communities respectively. Prima facie, Muslims appear to have much better social networks than other communities. However, it requires more in-depth investigation. Regarding the impact of this variable on the 'Adoption', various research studies have reported conflicting findings. For instance, a study undertaken in Ethiopia found that orthodox Christians and Muslims are less likely to adopt new agricultural technology as compared to other religious groups [4]. On the other hand, a study conducted in Nigeria does not find religion as a significant factor in the 'Adoption' [30]. This study also discovers that "religion" has little influence on 'Adoption'. The availability of credit also bears a positive and significant impact on the possibility of 'Access' indicating that the availability of financial resources provides leverage for farmers to get such services.

Among Wealth Indicators/Farm characteristics, 'assured means of irrigation' was found to be impacting both 'Access' and 'Adoption'. However, the variable Farm Size was found to be largely influencing the 'Access'. Interestingly, one of the major highlights of the NSSO 2003 is that marginal and small farmers have accessed far less information and a more narrow band of sources of information than medium and large farmers [3]. It may be noted here that 'Adoption' of new technology imposes opportunity costs on farmers who may have to forgo or adapt the existing system to the new requirements, with unforeseen outcomes. While large and medium farmers can tolerate it by experimenting on a small portion of their farmlands, small and marginal farmers cannot. If they do not find the information provided by extension services as reliable and timely they may not adopt the technology [36]. The emergence of 'assured means of irrigation' as a significant factor is an interesting finding in the sense that while agriculture shares 90 percent of the water use in India [15], only 46 percent of the arable land is irrigated. With a large chunk of land being low-productive, rain-fed and the reports of the research-extension link not absorbing the feedback from the farmers and extension staff, more so in arid and semi-arid agriculture, the conversion of 'Access' into 'Adoption' is bound to be low [36]. Government intervention becomes critical at this point to expand the irrigation network by (I) bringing additional land under irrigation and (ii) improving water use efficiency, as irrigation water use in India is 2 to 4 times that in the United States and China per unit of major crops [24]. Communication between farmers and extension services, as well as between farmers and research organizations/stations, may also be crucial in converting passive farmers to active ones. The policy implication is that intervention is necessary to strengthen extension services, which serve as the primary source of information for India's small and marginal farmers, who account for more than $85 \%$ of the country's farmers. Nonetheless, in the context of the data under investigation, a considerably lower correlation between large farms and 'Access' in comparison to medium farmers appears peculiar. However, given the relatively lower intensity of the personal involvement of bigger farmers with the agricultural operations, as compared to their relatively smaller counterparts, their direct interaction with the extension services may be relatively less and hence this result.

About the variable 'Regional Characteristics', the results exhibit that all five regions have better 'Access' than the reference region, i.e., Northern Region. However, Southern and Central regions show more robust 'Access'. When it comes to 'Adoption', the North-East region is far ahead of all. Both the Southern and Central regions appeared to have fallen flat as compared to the North-East when it came to 'Adoption'. The impact of ICT on 'Adoption' was found to be extremely weak among 'Other Variables,' indicating the importance of physical contacts rather than access to ICT tools. This is understandable, especially in view of the over 80 percent of the farmers being small and marginal and an overwhelming majority of them illiterate. The prior art also established that on-farm demonstration trials exercise the highest impact 
on the 'Adoption' [23]. In regard of the 'Frequency of Extension Contacts', 'the results indicate that the likelihood of 'Adoption' increases by 70 percent, 132 percent, 410 percent and 31 percent for monthly, seasonally, need-based and casual contacts respectively, as compared to the reference category, i.e., the daily contacts.

\section{Conclusions and Recommendations}

The study finds the strong influence of personal and household characteristics on both 'Access' and 'Adoption'. The better 'Access' of male $\mathrm{HOH}$ as compared to female $\mathrm{HOH}$ also calls for measures that facilitate better 'Access' and 'Adoption' by female $\mathrm{HOH}$. The socioeconomic and technology variables such as caste, gender, religion, and usage of ICT are found to be important for 'Access' but not for the 'Adoption'. The paper underlines that physical forms of extension services are far more important than the modern ICT driven services in the developing countries like India. It also emphasizes the need for improving the agricultural infrastructure and further diversifying the content of agricultural extension services as per the regional peculiarities. At the same time, the emergence of the need-based and seasonal contacts as significant factors for 'Adoption' suggests that a more focused approach shall yield better results. The study suggests strengthening of education and training on agricultural issues, especially for small and marginal farmers. It also recommends significant strengthening of these services with generous government support.

\section{REFERENCES}

[1] Abdallah, A. H., \& Abdul-Rahaman, "Determinants of access to agricultural extension services: evidence from smallholder rural women in Northern Ghana," Asian Journal of Agricultural Extension, Economics \& Sociology, vol. 9, no. 3, pp. 1-8. 2016.

[2] Acheampong, L. D., Frimpong, B. N., Adu-Appiah, A., Asante, B. O., \& Asante, M. D, "Assessing the information seeking behaviour and utilization of rice farmers in the Ejisu-Juaben municipality of Ashanti Region of Ghana," Agriculture \& Food Security, vol. 6, no. 3, pp. 1-9. 2017.

[3] Adhiguru, P., Birthal, P. S., \& Kumar, B. G., "Strengthening pluralistic agricultural information delivery systems in India," Agricultural Economics Research Review, 22(347-2016-16740), pp. 71-80. 2009.

[4] Admassie, A., \& Ayele, G., "Adoption of improved technology in Ethiopia," Ethiopian Journal of Economics, vol. 19. No. 1, pp. 155-179, 2010.

[5] Afrad, S. I., Wadud, F., \& Babu, S. C., "Reforms in agricultural extension service system in Bangladesh,"
In Agricultural Extension Reforms in South Asia, Academic Press, 2019, pp. 13-40.

[6] Anang, B. T., Bäckman, S., \& Sipiläinen, T., "Adoption and income effects of agricultural extension in northern Ghana." Scientific African, vol. 7, e00219. 2020.

[7] Anderson S, "Caste as an Impediment to Trade," American Economic Journal: Applied Economics, vol. 3, no. 1, pp. 239-263, 2011.

[8] Annie Hilda Ong'ayo, James Biriah Ndiso , "Social and Cultural Factors Influencing Gender Disparity in Farmers Field Schools Approach among Smallholder Farmers in Kilifi North Sub-County, Kilifi County," Universal Journal of Agricultural Research, Vol. 8, No. 5, pp. 158 - 164, 2020. DOI: 10.13189 /ujar.2020.080503.

[9] Babu, S. C., Glendenning, C. J., Okyere, K. A., \& Govindarajan, S. K., "Farmers' information needs and search behaviors: Case study in Tamil Nadu, India," 2012, (No. 1007-2016-79468).

[10] Babu S C, Joshi PK, Glendenning C J, Kwadwo A O and Rasheed S V., "The State of Agricultural Extension Reforms in India: Strategic Priorities and Policy Options," Agricultural Economics Research Review, vol. 26, no. 2, pp. 159-172, 2013.

[11] Birthal PS, Kumar S, Negi DS, Roy D., "The Impacts of Information on Returns from Farming: Evidence from a Nationally Representative Farm Survey in India," Agricultural Economics, vol. 46, no. 4, pp. 549-561, 2015.

[12] Bhogal, P., "Policy Imperatives for India's Small Farmers," ORF Issue Brief, December, 8. 2016.

[13] Brhane, G., Mammo, Y., \& Negusse, G., "Sources of information and information seeking behavior of smallholder farmers of Tanqa Abergelle Wereda, central zone of Tigray, Ethiopia," Journal of Agricultural Extension and Rural Development, vol. 9, no. 4, pp. 47-52, 2017.

[14] Danso-Abbeam, Gideon; Ehiakpor, D. and Aidoo, R., "Agricultural extension and its effects on farm productivity and income: Insight from Northern Ghana," Agriculture and Food Security, vol. 7, no. 74, pp. 1-10, 2018.

[15] Dhawan, V., "Water and Agriculture in India: Background paper for the South Asia expert panel during the Global Forum for Food and Agriculture" (GFFA) 2017, German Asia-Pacific Business Association. Accessed on Nov. 27, 2020.

https://www.oav.de/fileadmin/user upload/5Publikationen/ 5_Studien/170118_Study_Water_Agriculture_India.pdf

[16] Oduro-Ofori, E., Aboagye, A. P., \& Acquaye, N. A. E., "Effects of education on the agricultural productivity of farmers in the Offinso Municipality," International Journal of Development Research, vol. 4, no. 9, pp. 1951-1960, 2014.

[17] Ghimire, R; Wen-chi, H. Shresthaa, R. B., "Factors Affecting Adoption of Improved Rice Varieties among Rural Farm Households in Central Nepal," Rice Science, Vol. 22, no. 1, pp. 35-43, 2015.

[18] Gulati, A. Sharma, P. S., Anisha, Terway, P., "Agriculture Extension System in India: Review of Current Status, 
Trends and the Way Forward," Indian Council for Research on International Economic Relations (ICRIER). 2018. Also available on:

https://icrier.org/pdf/Agriculture-Extension-System-in-Indi a-2018.pdf

[19] Joshi, P. K., Kumar, P., and Parappurathu, S., "Public Investment in Agricultural Research and Extension in India," European Journal of Development Research, Vol. 27, no 3, pp. 438-451. 2015

[20] Joshi, V., \& Dhaliwal, R. K., "Enhanced role of ICT in Extension, Research and Governance towards achieving sustainable agriculture-A study of Punjab," International Journal, vol. 3, no. 10, pp. 554-558, 2015.

[21] Kabir, K. H., Roy, D., \& Kuri, S. K., "Information seeking behavior of the farmers to ensure sustainable agriculture," European Academic Research, vol. 2, no. 3, pp. 3723-3734, 2014.

[22] Krishna VV, Aravalath LM, Vikraman S. "Does caste determine farmer access to quality information?" PLoS ONE, vol. 14, no. 1,

2019:e0210721.https://doi.org/10.1371/journal.pone.02107 21

[23] Larochelle, C., J. Alwang, E. Travis, V.H. Barrera, and J.M. Dominguez, "Did You Really Get the Message? Using Text Reminders to Stimulate Adoption of Agricultural Technologies" The Journal of Development Studies, vol. 55, no. 4, pp. 548-564, 2019.

[24] Mishra, J.P. (2017). Revitalising Rainfed Agriculture in India. NITI Aayog, Government of India, New Delhi. Downloaded on Nov. 11, 2020 from: http://mospi.nic.in/sites/default/files /cocsso/1_NITI_Aayog_RevitaliseRainfedAgriculture.pdf

[25] Nagaratna, C. K., Uma, S., \& Hiremath, D. S., "Effectiveness of training programmes conducted by District Agricultural training centre," International Journal of Pure and Applied Biosciences, vol. 5, no. 6, pp.416-423, 2017.

[26] Nakano, Y., Tsusaka, T. W., Aida, T., \& Pede, V. O., "Is farmer-to-farmer extension effective? The impact of training on technology adoption and rice farming productivity in Tanzania," World Development, vol. 105, pp.336-351, 2018.

[27] Nandi, R and Nedumaran, S., "Agriculture Extension System in India: A Meta-analysis" Res. Jr. of Agril. Sci, vol. 10, no. 3, pp. 473-479, 2019

[28] Norton, George W. and Alwang, J., "Changes in Agricultural Extension and Implications for Farmer Adoption of New Practices," Applied Economic Perspectives and Policy, vol. 42, no.1, pp. 8-20, 2020.

[29] NSSO Report (2005). (61st, 66th \& 68th Round) on Household Consumption of Various Goods and Services in India.

[30] Oluwasusi, J. O., "Vegetable farmers attitude towards organic agriculture practices in selected states of South West Nigeria" Journal of Agricultural Extension and Rural Development, vol. 6, no. 7, pp. 223-230, 2014.
[31] Parmar, Ishwar S.; Soni, Peeyush; Kuwornu, John K. M. and Salin, Krishna R., "Evaluating Farmers' Access to Agricultural Information: Evidence from Semi-Arid Region of Rajasthan State, India," Agriculture, vol. 9, no. 3, pp. 60, 2019. ; https://doi.org/10.3390/agriculture 9030060

[32] Quisumbing, A.R., R. Meinzen-Dick, T.L. Rainey, A. Croppenstedt, J.A. Behrman, and A. Peterman., "Gender in Agriculture: Closing the Knowledge Gap," Dordrecht, The Netherlands: Springer. 2014

[33] Sajesh, V.K.; Padaria, R.N; Sadamate, V.V., "Pluralism in Agricultural Extension in India: Imperatives and Implications," Economic Affairs, vol. 63, no 4, pp. 1017-1025, 2018.

[34] Sajesh, V. K. and Suresh, A., "Public-Sector Agricultural Extension in India: A Note," Review of Agrarian Studies vol. 6, no. 1, pp.116-131, 2016.

[35] Singh, K.M.; Meena, M.S.; and Swanson, B.E. Swanson. (2013). 'Extension in India by Public Sector Institutions: An Overview' SSRN Electronic Journal. Accessed on Nov. 26, 2020 from:

https://www.researchgate.net/publication/256092297 Exte nsion in India by Public_Sector_Institutions An Overvi ew

[36] Tchaogang N, Corine S. Yang, J; and Chen, Y., "Determinants of Adoption of Agricultural Extension Services in the Centre Region of Cameroon," 2nd International Conference on Contemporary Education and Economic Development (CEED 2019).

[37] Tiwari, K. R., Nyborg, I. L., Sitaula, B. K., \& Paudel, G. S., "Analysis of the sustainability of upland farming systems in the Middle Mountains region of Nepal," International Journal of Agricultural Sustainability, vol. 6, no. 4, pp. 289-306, 2008.

[38] Vincent, A., \& Saravanan, R. (2020). Agricultural Extension and Advisory Systems in Tamil Nadu. by National Institute of Agricultural Extension Management (MANAGE)(An organisation of Ministry of Agriculture and Farmers' Welfare, Govt. of India) Rajendranagar, Hyderabad-500 030, Telangana State, India MANAGE, 2020.

[39] Wanigasundera, W.A.D.P. and Atapattu, N., "Extension reforms in Sri Lanka: lessons and policy options' in Agricultural Extension Reforms in South Asia: Status, Challenges, and Policy Options," Academic Press 2019, pp.79-98.

[40] Wossen,T., Abdoulaye, T., Alene, A; Haile, M. G.; Feleke, S. Olanrewaju, A; and Manyong,V., "Impacts of extension access and cooperative membership on technology adoption and household welfare," Journal of Rural Studies vol. 54, pp. 223-233, 2017.

[41] Wossen, T; Berger, T; and Di Falco, S., "Social capital, risk preference and adoption of improved farm land management practices in Ethiopia," Agricultural Economics, vol. 46, no. 1, pp. 81-97, 2015.

[42] Yimer, F., Abay, K., Degu, T., "Evaluation of modern agricultural technologies adoption and impact of adoption on productivity" FARA Res. Rep., vol. 4, no. 3, pp. 1-26, 2019. 